\title{
Recrystallization rims in zircon (Valle d'Arbedo, Switzerland): An integrated cathodoluminescence, LA-ICP-MS, SHRIMP, and TEM study
}

\section{Pierre Vonlanthen, ${ }^{1, *}$ John D. Fitz Gerald,${ }^{2}$ Daniela Rubatto, ${ }^{2}$ ANd Jörg Hermann ${ }^{2}$}

\author{
${ }^{1}$ Institute of Geology and Palaeontology, University of Lausanne, CH-1015 Lausanne, Switzerland \\ ${ }^{2}$ Research School of Earth Sciences, The Australian National University, Canberra, ACT 0200, Australia
}

\begin{abstract}
Recrystallization rims are a common feature of zircon crystals that underwent metamorphism. We present a microstructural and microchemical study of partially recrystallized zircon grains collected in polymetamorphic migmatites (Valle d'Arbedo, Ticino, Switzerland). The rims are bright in cathodoluminescence (CL), with sharp and convex contacts characterized by inward-penetrating embayments transgressing igneous zircon cores. Laser ablation-inductively coupled plasma-mass spectrometry (LA-ICP-MS) data and transmission electron microscopy (TEM) imaging indicate that the rims are chemically and microstructurally different from the cores. The rims are strongly depleted in REE, with concentrations up to two orders of magnitude lower than in the cores, indicating a significant loss of REE during zircon recrystallization. Enrichment in non-formula elements, such as $\mathrm{Ca}$, has not been observed in the rims. The microstructure of zircon cores shows a dappled intensity at and below the $100 \mathrm{~nm}$ scale, possibly due to radiation damage. Other defects such as pores and dislocations are absent in the core except at healed cracks. Zircon rims are mostly dapple-free, but contain nanoscale pores and strain centers, interpreted as fluid inclusions and chemical residues, respectively. Sensitive high-resolution ion microprobe (SHRIMP) U-Pb ages show that the recrystallization of the rims took place $>200 \mathrm{Ma}$ ago when the parent igneous zircon was not metamict. The chemical composition and the low-Ti content of the rims indicate that they form at sub-solidus temperatures (550-650 ${ }^{\circ} \mathrm{C}$ ). Recrystallization rims in Valle d'Arbedo zircon are interpreted as the result of the migration of chemical reaction fronts in which fluid triggered in situ and contemporaneous interface-coupled dissolution-reprecipitation mechanisms. This study indicates that strong lattice strain resulting from the incorporation of a large amount of impurities and structural defects is not a necessary condition for zircon to recrystallize. Our observations suggest that the early formation of recrystallization rims played a major role in preserving zircon from the more recent Alpine metamorphic overprint.
\end{abstract}

Keywords: Alps, microstructure, recrystallization, trace elements, U-Pb geochronology, zircon

\section{INTRODUCTION}

Zircon $\left(\mathrm{ZrSiO}_{4}\right)$ is a widely studied mineral in Earth sciences, first because it contains a large spectrum of geochemically important trace elements, such as $\mathrm{Y}, \mathrm{P}, \mathrm{Hf}, \mathrm{U}, \mathrm{Th}$, and the rare earth elements (REE), and second because it is known to be physically and chemically very robust. Those features make zircon a key mineral in various disciplines of geosciences, primary geochronology of magmatic, metamorphic, and sedimentary terranes, but also increasingly petrogenesis (e.g., Belousova et al. 2002; Hoskin and Schaltegger 2003) and geothermometry (Watson and Harrison 2005). Geological interpretation inferred from studies on zircon is not always straightforward, however, as zircon grains may contain a record of multiple geological events. Characterization of zircon-forming processes from zircon internal textures and chemistry is thus a prerequisite to validate and interpret compositional and isotopic measurements.

Rims of unzoned to weakly zoned zircon transgressing oscillatory zoned zircon cores have been reported abundantly over the last $25 \mathrm{yr}$. Van Breemen et al. (1987) attributed them to resorption by melt, followed by precipitation of new zircon. Other authors

*E-mail: pierre.vonlanthen@unil.ch
(Black et al. 1986; Claoué-Long et al. 1988; Schiotte et al. 1989) interpreted them as the result of recrystallization rather than new crystal growth. This interpretation was based on the preservation of primary zoning in the rims and deep embayments of the rims toward the inner parts of the grains. Similar rims were observed in metamict zircon from granitoid rocks (Pidgeon 1992; Nemchin and Pidgeon 1997; Pidgeon et al. 1998), granulites (Vavra et al. 1996, 1999) and eclogites (Rubatto and Gebauer 2000). For such zircon the idea of solid-state recrystallization triggered by migrating reaction fronts became predominant (Schaltegger et al. 1999; Hoskin and Black 2000; Rubatto and Gebauer 2000). Tomaschek et al. (2003) reported that recrystallization rims could also form in fully non-metamict zircon, thus indicating that radiation damage is not a necessary condition for zircon to recrystallize. Geisler et al. (2007) proposed two models (further discussed at the end of this paper) to account for the formation of recrystallization rims in metamict and non-metamict zircon. Recently, Harlov et al. (2011) also provided significant insights into similar processes, although their study focused into the mineral monazite. They experimentally produced and then characterized replacement rims, revealing crystallographic continuity with pre-existing core crystals reacted with alkali-bearing fluids.

Although knowledge of recrystallization features is crucial for 
correctly interpreting compositional and isotopic measurements, such as $\mathrm{U}-\mathrm{Pb}$ isotopic data and derived ages, our understanding of recrystallization rims in zircon is almost exclusively based on geochemistry and standard scanning electron microscopy observations, using either cathodoluminescence (CL) or backscatter electron (BSE) imaging (see Corfu et al. 2003 for a review). Transmission electron microscopy (TEM) analyses have been carried out in several zircon studies, but they focus either on radiation damage (Bursill and McLaren 1966; Headley et al. 1981; Yada et al. 1987; Murakami et al. 1991; McLaren et al. 1994; Weber et al. 1994; Capitani et al. 2000; Palenik et al. 2003), shock deformation (Leroux et al. 1999), or zircon outgrowth formation (Hay and Dempster 2009; Hay et al. 2010). Current data, however, provides little information about the nanoscale of recrystallization rims in zircon. In this paper we present a TEM-based study of recrystallization rims in zircon leading to a substantial increase in our understanding of recrystallization processes. The study is completed by LA-ICP-MS and SHRIMP analyses to address the question of their origin and petrological significance.

\section{MATERials}

The sample investigated (sample VAL3) is a garnet-bearing migmatite collected in the Valle d'Arbedo (Ticino, Switzerland) within the Southern Steep Belt of the Central Alps, an intensely deformed region of the Penninic basement just north of the Insubric Line (Fig. 1a). This polymetamorphic basement underwent Variscan metamorphism in the Late Carboniferous, was intruded by granodiorites in the Permian and finally underwent migmatization in the Oligocene (Gebauer 1993). The sample is from a leucocratic portion within a meter-sized lens (Fig. 1b), which is surrounded by garnet-free migmatites of Alpine age ( $\sim 31$ to $26 \mathrm{Ma}$, sample VAL4 in Rubatto et al. 2009). The mineralogical assemblage mainly consists of plagioclase, quartz, K-feldspar, garnet, and biotite. Garnet forms centimeter-sized porphyroblasts, whereas biotite defines the foliation.

Irregular to subhedral zircon crystals are $100-500 \mu \mathrm{m}$ in length. The internal structure shows CL-dark cores with obvious primary oscillatory zoning cut by transgressive CL-bright rims of unzoned to weakly zoned zircon (Fig. 2). The contact between core and rim is sharp in CL and forms convex, inward-penetrating embayments. A few macroscopic CL-dark inclusions have been observed within or in contact with the CL-bright domains.

\section{MeTHODS}

About 150 zircon grains were separated from the VAL3 leucocratic layer after rock crushing using conventional heavy liquid and magnetic properties. The grains were then mounted in epoxy resin and polished to about half their thickness. Preliminary panchromatic CL imaging was used to identify the crystals of interest, i.e., those characterized by well-developed CL-bright rims. CL images were taken at the Electron Microscopy Unit (EMU) of the Australian National University (ANU) using Hitachi $4300 \mathrm{SE} / \mathrm{N}$ and Hitachi S225ON scanning electron microscopes (SEM), both operated at $15 \mathrm{kV}$ and $\sim 20 \mathrm{~mm}$ working distance.

Trace-element composition was measured by laser ablation-inductively coupled plasma-mass spectrometry (LA-ICP-MS) at the Research School of Earth Sciences (RSES, ANU) both in the grain cores and rims. The instrument employed a pulsed $\operatorname{ArF}(193 \mathrm{~nm})$ Excimer laser with $100 \mathrm{~mJ}$ energy at a repetition rate of $5 \mathrm{~Hz}$ coupled to a Hewlett Packard Agilent 7500 quadrupole ICP-MS (Eggins et al. 1998). A NIST 612 glass was used as external standard, and stoichiometric $\mathrm{SiO}_{2}(32.45 \mathrm{wt} \%)$ was taken as internal standard. Accuracy was assessed against BCR-2G glass and was generally better than $10 \%$. Analyses were performed with a round spot measuring $32 \mu \mathrm{m}$ in diameter.

The zircon grains were analyzed for $\mathrm{U}, \mathrm{Th}$, and $\mathrm{Pb}$ using sensitive highresolution ion microprobe (SHRIMP II and SHRIMP RG) at the RSES (ANU). Instrumental conditions and data acquisition were as described by Williams (1998). The data were collected in sets of six scans throughout the masses and a reference zircon grain was analyzed each fourth analysis. The measured ${ }^{206} \mathrm{~Pb} /{ }^{238} \mathrm{U}$ ratio was corrected using reference zircon from the Temora granodiorite (Black et al. 2003). Uranium contents were standardized to SL13 zircon (216 U ppm). The analyses were corrected for common $\mathrm{Pb}$ based on the measured ${ }^{208} \mathrm{~Pb} /{ }^{206} \mathrm{~Pb}$, following Williams (1998). Data evaluation and age calculation were carried out using the software Squid 1 and Isoplot/Ex (Ludwig 2003), respectively. The com-
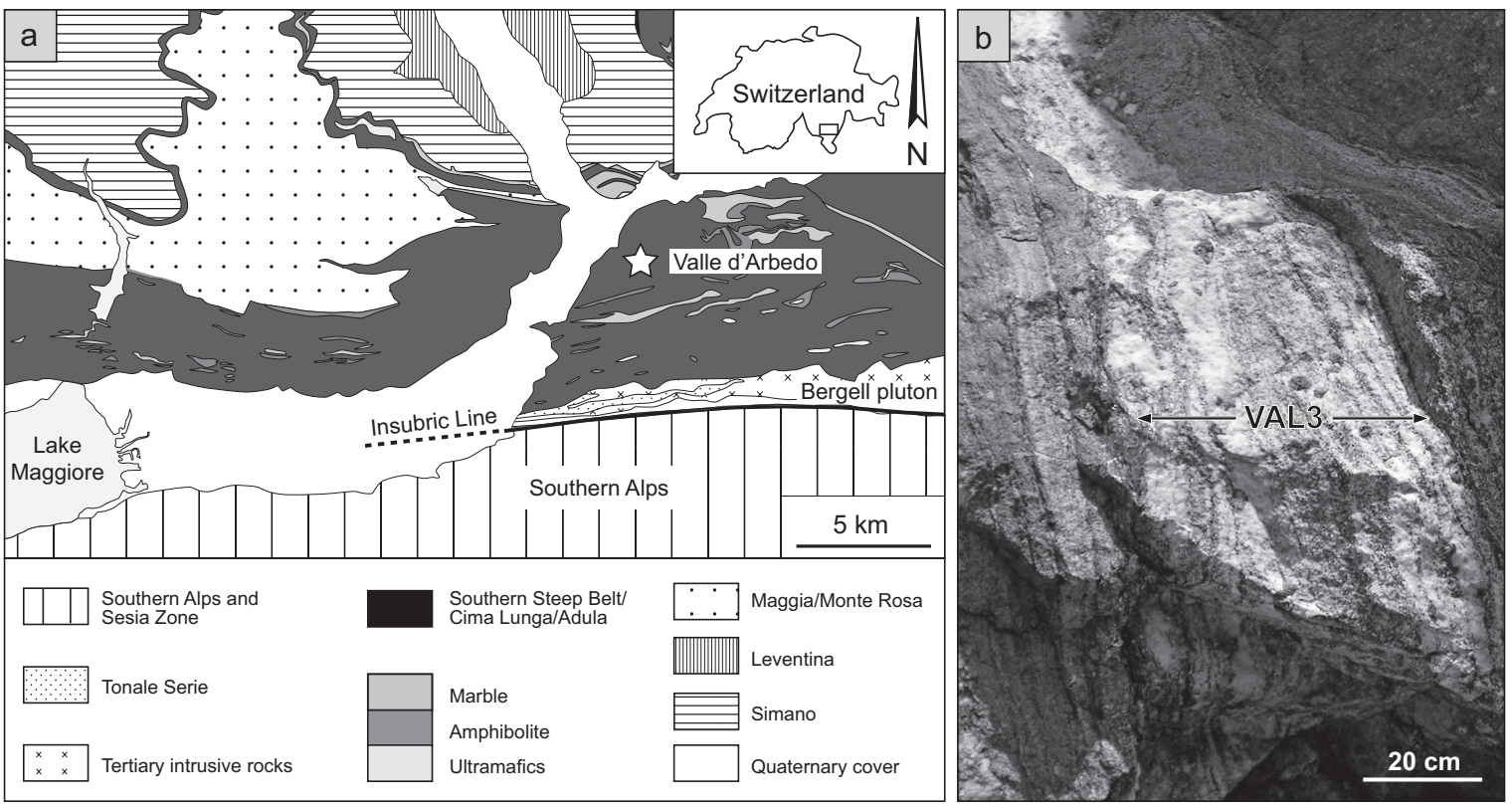

FIGURE 1. (a) Simplified geological map of the Southern Steep Belt (after Berger et al. 2005). The sampling location (726800/118600; Swiss coordinate system) is indicated by a star. (b) VAL3 leucosome surrounded by a melanocratic country rock. 
mon $\mathrm{Pb}$ composition was assumed to be that predicted by the model of Stacey and Kramers (1975). U-Pb data were collected over two analytical sessions using the same standard, with the two analytical sessions having calibration errors of 1.8 and $2.9 \%(2 \sigma)$, which was propagated to single analyses. Average ages were quoted at $95 \%$ confidence level (c.1.).

One zircon crystal (VAL3-29) was selected for TEM analysis based on panchromatic CL images. The crystal is a broken fragment of a larger subhedral specimen. It was chosen not only because it contains well-developed rims, but also because its large dimensions and lack of fresh fractures enabled standard TEM preparation through ion-milling. The epoxy mount containing the selected zircon was glued to a thin section with demountable resin (Crystalbond), and ground to a thickness of $30 \mu \mathrm{m}$. A $3 \mathrm{~mm} \mathrm{Cu}$ grid was then glued to the thin section with Araldite, extracted, and thinned to electron transparency by standard Ar-ion-milling (Strecker et al. 1999). Correlation of features (such as corners of irregularities at the crystal edge) visible in all images from low-magnification CL and light microscope (both before and after ion-thinning) enabled regions of interest to be selected with only a few micrometers of uncertainty across the final ion-thinned specimens. The places corresponding to CL features were therefore easily found in the TEM specimens. The TEM imaging was carried out at the RSES (ANU) using a Philips CM300 TEM operated at $300 \mathrm{kV}$, and fitted with a Gatan 694 slow-scan digital camera. The imaging technique involves tilting of samples to control the diffraction contributing to image contrast. The two main types of images showing diffraction contrast are known as bright-field (BF) and dark-field (DF) (for further details, see McLaren 1991). In such images, defects can be visible due to diffraction effects in regions of significant crystal distortion, but there are also image features such as contours of intensity (e.g., extinction and bend contours), which develop in perfect crystal and must not be confused with defects.

\section{RESULTS}

\section{LA-ICP-MS analyses}

The trace-element composition of zircon was measured by LA-ICP-MS (Table 1). Chondrite-normalized patterns from both the CL-bright rims and the CL-dark cores show a typical steeply rising slope from the LREE to the HREE with a strong positive Ce-anomaly and a weak negative Eu-anomaly (Fig. 3a). Zircon rims, however, contain only $5 \%$ of the total trace elements hosted in the cores (Table 1), suggesting a significant loss of REE during the formation of the rims. The stronger depletion in MREE in
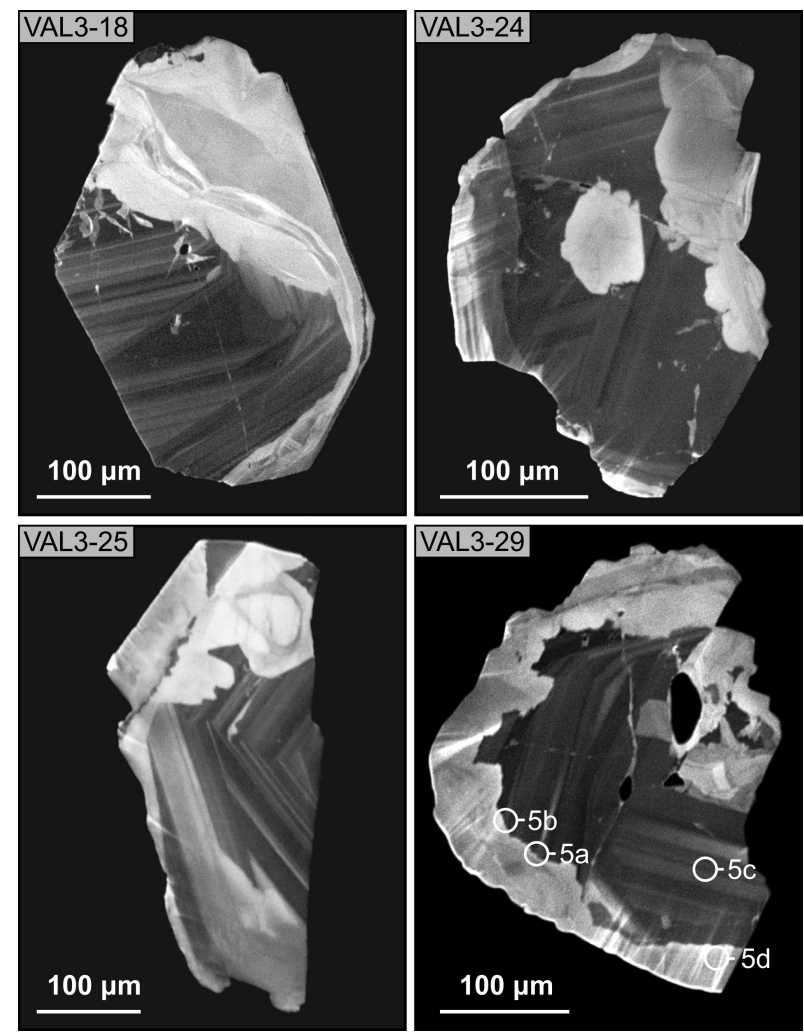

FIGURE 2. Panchromatic CL images of four zircon grains from the Valle d'Arbedo (Ticino, Switzerland) showing well-developed CL-bright rims cutting primary oscillatory zoning. Circles in zircon VAL3-29 indicate the locations imaged by TEM and shown in Figure 5.

TABLE 1. LA-ICP-MS data (in ppm) of zircon from the Valle d'Arbedo

\begin{tabular}{|c|c|c|c|c|c|c|c|c|c|c|c|c|}
\hline \multicolumn{6}{|c|}{ Spots in cores } & \multicolumn{7}{|c|}{ Spots in rims } \\
\hline & VAL3-1.2 & VAL3-4.2 & VAL3-8.2 & VAL3-10.2 & VAL3-16.1 & VAL3-1.1 & VAL3-4.1 & VAL3-6.2 & VAL3-11.2 & VAL3-12.1 & VAL3-14.1 & VAL3-15.1 \\
\hline $\bar{P}$ & 96 & 63 & 57 & 287 & 55 & 31 & 48 & 25 & 29 & 35 & 28 & 20 \\
\hline $\mathrm{Ca}$ & bdl & bdl & bdl & bdl & 82 & bdl & bdl & bdl & bdl & bdl & bdl & bdl \\
\hline $\mathrm{Ti}$ & 4.6 & 16 & 1.2 & 5.2 & 1.6 & bdl & 2.3 & 1.1 & 2.1 & 1.4 & 1.7 & 1.9 \\
\hline $\mathrm{Sr}$ & 0.41 & 0.45 & 0.27 & 0.37 & 0.19 & 0.087 & 0.18 & 0.075 & 0.076 & 0.088 & 0.075 & 0.092 \\
\hline Y & 1823 & 2909 & 1304 & 2665 & 385 & 45 & 92 & 64 & 84 & 121 & 21 & 110 \\
\hline $\mathrm{Nb}$ & 15 & 17 & 17 & 25 & 8.2 & 0.61 & 3.4 & 0.59 & 1.6 & 1.1 & 0.63 & 1.6 \\
\hline La & 0.042 & 0.055 & bdl & 0.30 & 0.022 & bdl & 0.031 & bdl & 0.030 & bdl & bdl & 0.012 \\
\hline $\mathrm{Ce}$ & 6.4 & 33 & 9.8 & 28 & 3.9 & 0.29 & 1.0 & 0.37 & 0.51 & 0.55 & 0.15 & 1.3 \\
\hline $\operatorname{Pr}$ & 0.49 & 0.54 & 0.11 & 2.1 & 0.042 & bdl & 0.024 & 0.007 & 0.012 & 0.008 & bdl & 0.009 \\
\hline $\mathrm{Nd}$ & 7.3 & 8.4 & 2.4 & 25 & 0.68 & bdl & 0.14 & bdl & 0.12 & 0.13 & bdl & bdl \\
\hline Sm & 14 & 19 & 5.2 & 37 & 1.5 & 0.073 & 0.20 & 0.11 & 0.14 & 0.30 & bdl & 0.14 \\
\hline $\mathrm{Eu}$ & 7.7 & 13 & 3.3 & 21 & 0.97 & 0.059 & 0.091 & 0.11 & 0.084 & 0.27 & bdl & 0.13 \\
\hline $\mathrm{Gd}$ & 61 & 101 & 34 & 142 & 8.7 & 0.61 & 0.87 & 1.0 & 0.93 & 2.1 & 0.28 & 1.2 \\
\hline $\mathrm{Tb}$ & 21 & 34 & 12 & 42 & 3.1 & 0.25 & 0.39 & 0.41 & 0.49 & 0.83 & 0.13 & 0.56 \\
\hline Dy & 235 & 373 & 149 & 415 & 40 & 3.9 & 6.8 & 5.8 & 7.7 & 12 & 1.8 & 9.2 \\
\hline Ho & 71 & 111 & 49 & 107 & 14 & 1.6 & 3.2 & 2.3 & 3.0 & 4.5 & 0.75 & 3.8 \\
\hline $\mathrm{Er}$ & 282 & 424 & 210 & 373 & 63 & 8.8 & 18 & 12 & 16 & 22 & 4.0 & 21 \\
\hline Tm & 56 & 80 & 42 & 68 & 13 & 2.3 & 4.7 & 3.0 & 3.8 & 5.4 & 1.1 & 5.4 \\
\hline Yb & 457 & 631 & 360 & 525 & 117 & 24 & 49 & 30 & 37 & 53 & 12 & 54 \\
\hline Lu & 68 & 86 & 55 & 68 & 19 & 4.8 & 9.0 & 5.5 & 6.5 & 9.7 & 2.2 & 9.9 \\
\hline $\mathrm{Ta}$ & 15 & 4.9 & 8.3 & 5.2 & 15 & 1.6 & 3.3 & 0.57 & 2.1 & 1.4 & 0.78 & 1.9 \\
\hline $\mathrm{Pb}$ & 15 & 35 & 56 & 45 & 3.4 & 0.12 & 0.58 & 0.28 & 0.99 & 1.9 & 0.11 & 0.66 \\
\hline Th & 292 & 736 & 1095 & 968 & 74 & 3.1 & 18 & 5.9 & 21 & 41 & 2.4 & 15 \\
\hline U & 509 & 703 & 1046 & 873 & 173 & 54 & 62 & 37 & 69 & 159 & 20 & 64 \\
\hline Total & 4056 & 6399 & 4517 & 6729 & 1083 & 182 & 323 & 194 & 286 & 473 & 97 & 322 \\
\hline
\end{tabular}



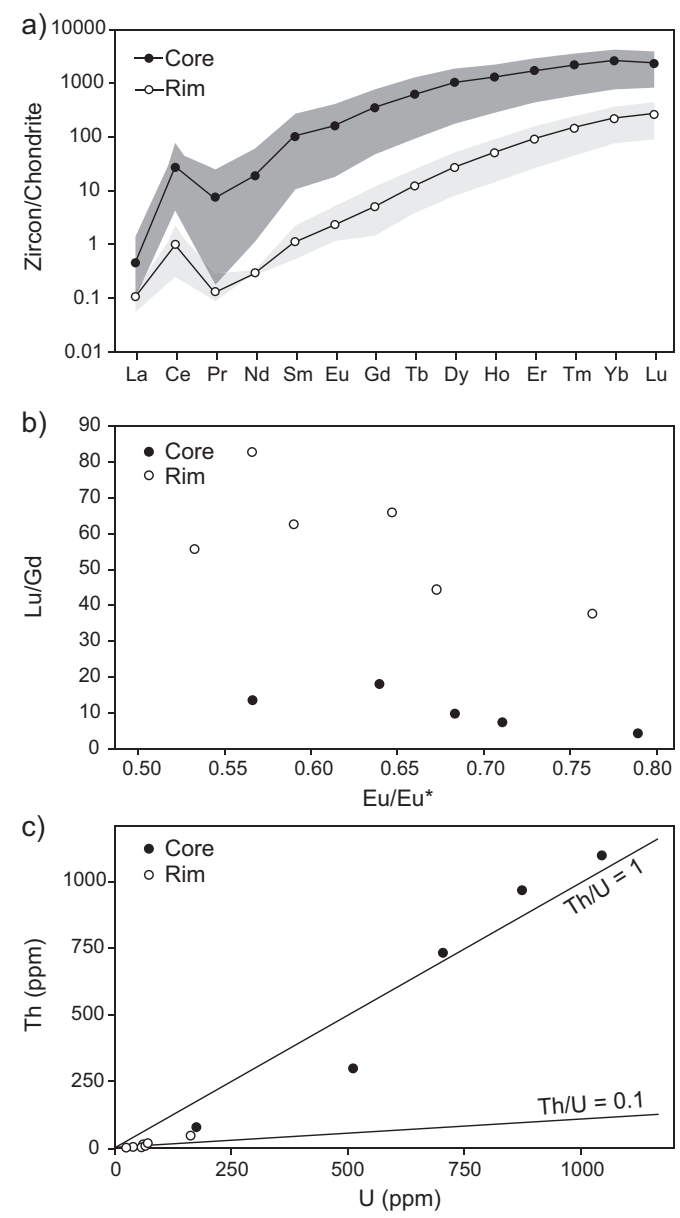

FIGURE 3. LA-ICP-MS chemical composition from cores and rims. (a) Average REE chondrite-normalized patterns. The fields of core and rim zircon are shown in dark and light gray, respectively. (b) Anomaly of Eu vs. Lu/Gd as an indicator of the steepness of REE patterns. (c) Thorium vs. U diagram. the rims compared to that in the cores results in a steeper slope of the chondrite-normalized pattern, leading to higher Lu/Gd ratios in the rims than in the cores (Fig. 3b). Thorium and $\mathrm{U}$ are also unequally distributed, with $\mathrm{Th} / \mathrm{U}$ ratios varying up to one order of magnitude between the rims and the cores (Fig. 3c). Calcium, recently used together with $\mathrm{Al}$ and $\mathrm{Fe}$ concentrations to determine the mechanism of recrystallization (Geisler et al. 2007), is generally below the detection limit of $0.008 \mathrm{wt} \%$.

\section{SHRIMP analyses}

SHRIMP U-Pb analyses performed on zircon cores and rims (Fig. 4) spread along Concordia with the oldest age component at $\sim 515 \mathrm{Ma}$ (mainly cores), a large group at 490-460 Ma (mainly rims), and isolated ages down to $200 \mathrm{Ma}$ (only rims). Most of the cores (6/9, average ${ }^{206} \mathrm{~Pb} /{ }^{238} \mathrm{U}$ age $515 \pm 12 \mathrm{Ma}, 95 \%$ c.l., MSWD 2.0) fall within the first group, with the oldest 4 analyses being indeed cores (average age $524 \pm 9 \mathrm{Ma}$, MSWD 0.17). Three other analyses of cores have returned ages in the broad peak at 470-460 Ma, which mainly comprises rim analyses. One single analysis, collected in an isolated and euhedral overgrowth that is distinct in CL from all the other rims, has yielded an age of $30.1 \pm 0.5 \mathrm{Ma}$ (Table 2).

\section{Transmission electron microscopy}

Detailed examination by TEM of one zircon crystal, VAL329 , has indicated a different microstructure in the core compared to that in the rim (Figs. 5a-5b). The diffraction contrast images of the core reveal a microstructure with dappled intensity at and below the $100 \mathrm{~nm}$ scale. Dappling indicates that the crystal lattice is somewhat strained on a very fine scale, which could be due to radiation-induced damage or perhaps even to the presence of isolated zircon domains such as those of variable crystallinity described by Chakoumakos et al. (1987). Defects unrelated to radiation damage are absent in the core except at healed cracks, where microscale pores are associated with dislocation arrays that locally mark very low angles of crystallographic misorientation (Fig. 5c). No submicrometer oscillatory zoning has been a)

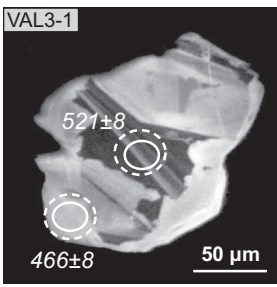

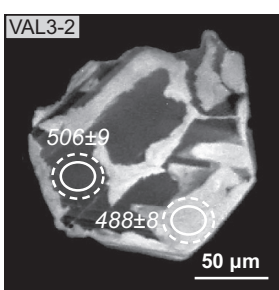
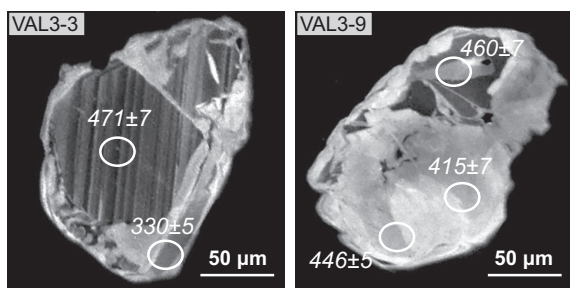

c)

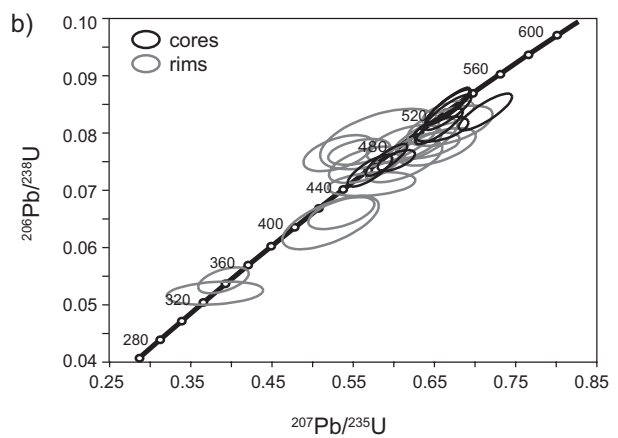

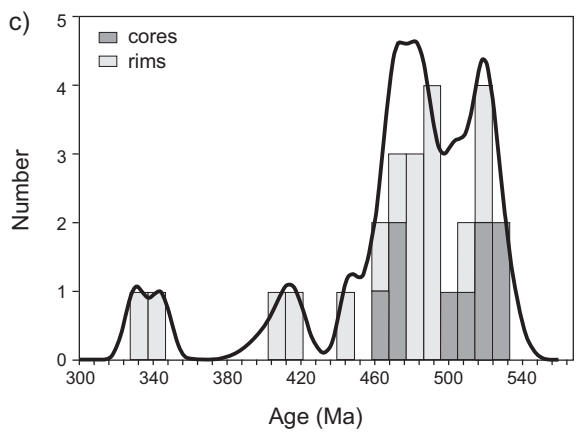

FIGURE 4. (a) Panchromatic CL images of dated zircon grains. Some cores preserve Cambrian ages, whereas others have been reset possibly during the Ordovician event that is recorded by the age of most of the rims. Dotted circles indicate location of LA-ICP-MS trace element analyses, whereas white circles represent SHRIMP $\mathrm{U}-\mathrm{Pb}$ analyses. Numbers are apparent ${ }^{206} \mathrm{~Pb} /{ }^{238} \mathrm{U}$ ages in $\mathrm{Ma} \pm 1 \sigma$. (b) Concordia diagram of SHRIMP $\mathrm{U}-\mathrm{Pb}$ zircon analyses (see text for discussion). Error ellipses represent $2 \sigma$. (c) Probability density diagram and histogram of zircon $\mathrm{U}-\mathrm{Pb}$ ages. Cores are mainly between 500-530 Ma, whereas rims are mainly $<500$ $\mathrm{Ma}$. Two analyses with ages of 200 and $30 \mathrm{Ma}$ are not plotted. 

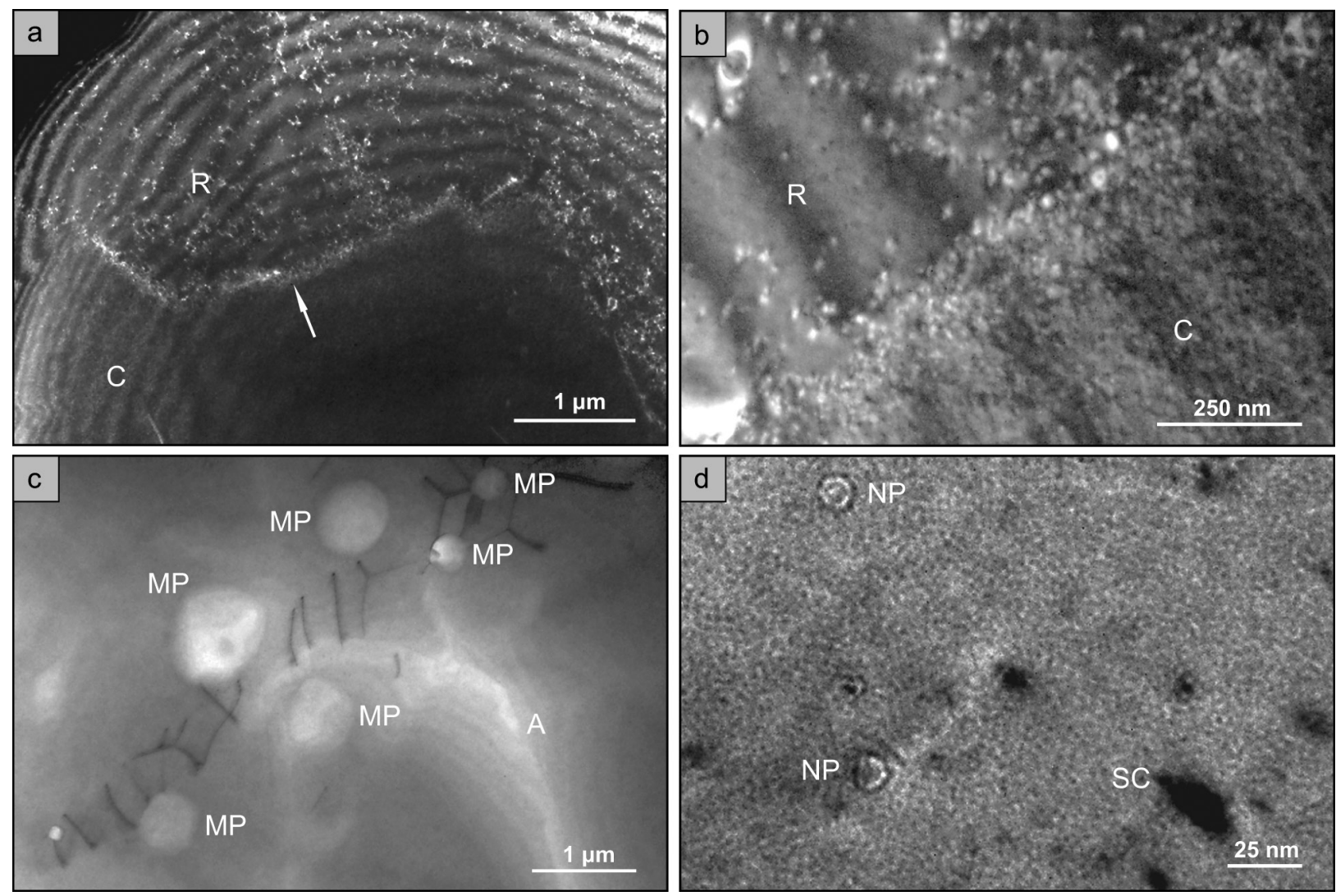

FIGURE 5. TEM images of zircon VAL3-29 (CL in Fig. 2). (a) DF TEM image of one region showing an interface (arrow) between the recrystallization rim (R) and the primary core (C). (b) DF TEM image of the interface showing the defect-bearing recrystallization rim and the uniformly dappled primary core. (c) BF TEM image of an array of dislocations (dark lines) interacting with a family of microscale pores (MP), resulting from healing of an isolated crack in the core. The bright (thinner) region (A) in the lower right of the image is an artifact of the ion-thinning used to prepare the TEM specimen. (d) BF TEM image of the nanoscale pores (NP) and strain centers (SC) typical of the recrystallization rim. Note that strain centers apparent as dark specks in $\mathbf{d}$ correspond to bright specks in DF images (a and $\mathbf{b})$. Contrast across the field of view in $\mathbf{d}$ at the $<5 \mathrm{~nm}$ scale is created by the large image underfocus required to highlight nanopores.

TABLE 2. SHRIMP U-Pb data of zircon from the Valle d'Arbedo

\begin{tabular}{|c|c|c|c|c|c|c|c|c|c|c|c|c|}
\hline Spot label & Initial ${ }^{206} \mathrm{~Pb} \%$ & $\mathrm{U}(\mathrm{ppm})$ & Th (ppm) & Th/U & ${ }^{207} \mathrm{~Pb} /{ }^{235} \mathrm{U}$ & \% error & ${ }^{206} \mathrm{~Pb} /{ }^{38} \mathrm{U}$ & \% error & er. cor. & ${ }^{206} \mathrm{~Pb} /{ }^{238} \mathrm{U}$ age & \pm 1 sigma & CL domain \\
\hline VAL3-6.1 & 6.79 & 493 & 4 & 0.01 & - & - & 0.00468 & 1.70 & - & 30.1 & 0.5 & overgrowth \\
\hline VAL3-8.3 & 0.63 & 137 & 5 & 0.03 & 0.2226 & 3.31 & 0.03130 & 1.25 & 0.378 & 200 & 2 & rim \\
\hline VAL3-3.1 & 2.76 & 150 & 18 & 0.12 & 0.3845 & 6.33 & 0.05254 & 1.57 & 0.248 & 330 & 5 & rim \\
\hline VAL3-10.1 & 0.50 & 68 & 3 & 0.04 & 0.3949 & 3.23 & 0.05479 & 1.68 & 0.522 & 344 & 6 & rim \\
\hline VAL3-8.1 & 1.66 & 55 & 10 & 0.18 & 0.5268 & 4.60 & 0.06485 & 2.93 & 0.637 & 405 & 12 & rim \\
\hline VAL3-9.1 & 1.66 & 52 & 8 & 0.15 & 0.5400 & 3.08 & 0.06652 & 1.72 & 0.558 & 415 & 7 & rim \\
\hline VAL3-9.3 & 0.00 & 80 & 6 & 0.08 & 0.5772 & 3.82 & 0.07158 & 1.19 & 0.312 & 446 & 5 & rim \\
\hline VAL3-9.2 & 0.15 & 233 & 104 & 0.45 & 0.5751 & 1.96 & 0.07390 & 1.53 & 0.782 & 460 & 7 & core \\
\hline VAL3-1.1 & 0.88 & 50 & 3 & 0.06 & 0.5691 & 3.19 & 0.07494 & 1.73 & 0.543 & 466 & 8 & rim \\
\hline VAL3-5 & 1.06 & 55 & 9 & 0.17 & 0.6170 & 3.13 & 0.07556 & 1.98 & 0.633 & 470 & 9 & rim \\
\hline VAL3-13.1 & 0.11 & 308 & 116 & 0.38 & 0.6075 & 1.55 & 0.07570 & 0.99 & 0.638 & 470 & 5 & core \\
\hline VAL3-3.2 & 0.00 & 372 & 87 & 0.24 & 0.5955 & 1.77 & 0.07581 & 1.51 & 0.853 & 471 & 7 & core \\
\hline VAL3-12.1 & 0.27 & 61 & 10 & 0.16 & 0.5366 & 3.29 & 0.07698 & 1.67 & 0.509 & 478 & 8 & rim \\
\hline VAL3-15.1 & 0.29 & 86 & 21 & 0.24 & 0.5619 & 2.77 & 0.07720 & 1.19 & 0.431 & 479 & 6 & rim \\
\hline VAL3-4.1 & 0.70 & 52 & 9 & 0.18 & 0.6581 & 2.94 & 0.07808 & 1.72 & 0.585 & 485 & 8 & rim \\
\hline VAL3-11.2 & 0.37 & 92 & 22 & 0.24 & 0.6467 & 2.46 & 0.07835 & 1.18 & 0.479 & 486 & 6 & rim \\
\hline VAL3-2.1 & 0.00 & 64 & 5 & 0.08 & 0.6174 & 3.06 & 0.07862 & 1.70 & 0.557 & 488 & 8 & rim \\
\hline VAL3-7.1 & 0.00 & 93 & 3 & 0.04 & 0.6420 & 2.63 & 0.07927 & 1.93 & 0.736 & 492 & 9 & rim \\
\hline VAL3-14.1 & 2.64 & 25 & 3 & 0.13 & 0.5869 & 5.09 & 0.07944 & 2.71 & 0.534 & 493 & 13 & rim \\
\hline VAL3-16.1 & 0.00 & 154 & 58 & 0.37 & 0.6630 & 2.06 & 0.08116 & 1.10 & 0.533 & 503 & 6 & core \\
\hline VAL3-2.2 & 0.12 & 520 & 472 & 0.91 & 0.6603 & 1.83 & 0.08165 & 1.56 & 0.851 & 506 & 9 & core \\
\hline VAL3-6.2 & 1.11 & 39 & 5 & 0.14 & 0.6737 & 3.17 & 0.08177 & 1.76 & 0.555 & 507 & 9 & rim \\
\hline VAL3-17.1 & 0.21 & 77 & 19 & 0.24 & 0.7199 & 2.58 & 0.08346 & 1.23 & 0.477 & 517 & 6 & rim \\
\hline VAL3-6.3 & 0.29 & 146 & 31 & 0.21 & 0.6713 & 1.96 & 0.08394 & 1.08 & 0.549 & 520 & 6 & rim \\
\hline VAL3-1.2 & 0.12 & 412 & 206 & 0.50 & 0.6713 & 1.75 & 0.08411 & 1.51 & 0.859 & 521 & 8 & core \\
\hline VAL3-8.2 & 0.03 & 637 & 408 & 0.64 & 0.7173 & 1.88 & 0.08416 & 1.56 & 0.830 & 521 & 9 & core \\
\hline VAL3-4.2 & 0.03 & 490 & 392 & 0.80 & 0.6713 & 1.72 & 0.08502 & 1.51 & 0.877 & 526 & 9 & core \\
\hline VAL3-10.2 & 0.03 & 806 & 747 & 0.93 & 0.6713 & 1.65 & 0.08531 & 1.49 & 0.903 & 528 & 9 & core \\
\hline
\end{tabular}


observed in the core, despite CL-zoning being obvious (though low in contrast) at a macroscopic scale.

In contrast to the core, the rim is mostly dapple-free, suggesting that it has not been damaged by radiation. This is consistent with the low content of the radiogenic elements $U$ and $T h$ in the rims $(<100 \mathrm{ppm})$ compared to that in the cores (mostly 500-1000 ppm, Table 1) and the consequent radiation dose of the rims (see below). Unlike the core, the rim contains structural defects such as spherical, possibly fluid-bearing, nanoscale pores about $10 \mathrm{~nm}$ in diameter and 5 to $30 \mathrm{~nm}$ wide strain centers (Fig. $5 \mathrm{~d}$; see discussion for explanation and interpretation of those microstructural terms). Nanoscale pores and strain centers are unevenly distributed throughout the rim. Elongated clusters of strain centers, suggestive of nanoscale inclusions, can be seen in places surrounded by defect-free areas.

The crystal regions in core and rim are almost perfectly aligned (i.e., essentially zero misorientation) as evidenced by the continuity of diffraction-contrast fringes (dark-light contouring spaced at 100-200 nm in Figs. 5a-5b) across the core-rim interface in TEM images. The interface between the primary core and the rim is possibly rich in defects of the strain-center type (see specks at the boundary in Fig. 5a), but this cannot be confirmed with certainty.

\section{DISCUSSION}

\section{Zircon history}

The formation of rims in metamorphic zircon can be attributed to three different processes: (1) subsolidus metamorphic reactions involving the breakdown of Zr-bearing minerals (Fraser et al. 1997; Pan 1997; Degeling et al. 2001), (2) crystallization from anatectic melts (Roberts and Finger 1997; Schaltegger et al. 1999; Rubatto et al. 2009), and (3) solid-state in situ recrystallization triggered by fluids (Pidgeon 1992; Vavra et al. 1999; Hoskin and Black 2000; Tomaschek et al. 2003; Geisler et al. 2007). Distinction between these processes is generally made based on morphological, geochemical, and microstructural criteria. The investigated VAL3 zircon grains display an irregular to subhedral shape, inward-penetrating embayments of the core-rim interface and the preservation of faint primary CL-zoning (e.g., VAL3-29 rim in Fig. 2) and convolute zoning (e.g., VAL3-3 rim in Fig. 4). These observations are neither in line with subsolidus metamorphic growth nor with crystallization from a melt, but indicate recrystallization in a fluid-bearing environment. This is further supported by the much lower trace-element content of the rims with respect to that of the cores (Hoskin and Black 2000) and the occurrence of porosity in the rims (Putnis 2002; Geisler et al. 2007; Nasdala et al. 2009). It is therefore concluded that the rims have been caused by a recrystallization front that migrated into the pre-existing igneous grains.

$\mathrm{U}-\mathrm{Pb}$ zircon dating has shown that the majority of VAL3 zircon cores preserve an age between $\sim 530$ and $505 \mathrm{Ma}$. Significantly younger ages of three oscillatory-zoned cores $(\sim 470$ $\mathrm{Ma}$ ) were likely produced by partial $\mathrm{U}-\mathrm{Pb}$ resetting that did not significantly change the CL zoning, or affected it at a microscale not detected by CL imaging. Therefore, it can be inferred that the age of the intrusion of the magmatic protolith is Middle Cambrian, an age best constrained by the oldest analyzed cores $(524 \pm 9 \mathrm{Ma})$.
The major age peak at 490-460 Ma in Figure 4c pertains to the rim analyses. This cluster is suggestive of a significant post-magmatic event in the Ordovician that produced the zircon recrystallization, but the spread in ages is such that a precise age cannot be calculated. Additionally, a few unzoned zircon domains preserve ages of $\sim 515 \mathrm{Ma}$, thus overlapping the core ages, and one is as young as $200 \mathrm{Ma}$. This age distribution does not allow constraining the time of recrystallization. It rather suggests a complex and possibly multi-stage disturbance of the U-Pb system that could have been locally incomplete. At the scale of the analysis $(20 \mu \mathrm{m})$, this would result in mixing between magmatic and variably reset portions, even in domains displaying homogeneous, metamorphic-like CL zoning, that in turn would yield apparent ages of dubious significance. Indication of the relative timing of zircon recrystallization vs. major-mineral-forming events comes from the trace-element composition of the zircon grains. The steep HREE pattern, weak negative Eu-anomaly and low-Ti content of the recrystallization rims is not in line with the present mineral assemblage. Recrystallization in the presence of garnet (sink for HREE) and K-feldspar (sink for Eu) would create zircon depleted in HREE and Eu (Rubatto 2002). Additionally, the low-Ti content of the zircon rims (1-2 ppm) corresponds to low temperatures $\left(\sim 550-650{ }^{\circ} \mathrm{C}\right.$ assuming a $\mathrm{TiO}_{2}$ activity of 0.5 and according to the calibration of Watson et al. 2006), whereas the mineral assemblage is typical of upper amphibolite to granulite metamorphic conditions. Hence, we suggest that the recrystallization process did not occur during the metamorphism that produced the major rock-forming minerals.

The remarkable preservation of VAL3 zircon grains during the Alpine metamorphism is noteworthy. Rubatto et al. (2009) have shown that the Valle d'Arbedo polymetamorphic basement was maintained at temperatures ranging between 620 and 700 ${ }^{\circ} \mathrm{C}$ for about $10 \mathrm{Ma}$ during the Oligocene with limited pressure variations. Over this period, melting occurred intermittently and heterogeneously whenever fluid was present (Burri et al. 2005; Berger et al. 2008). In samples surrounding VAL3 (VAL1, VAL2, and VAL4 in Rubatto et al. 2009), Alpine migmatization led to the formation of euhedral zircon overgrowths with ages spanning from 32 to $22 \mathrm{Ma}$. In VAL3 zircon grains, however, such overgrowths are rarely observed and only one of them (VAL36.1) has been dated (30.1 $\pm 0.5 \mathrm{Ma}$, see Table 2$)$. On the other hand, recrystallization rims with ages $>200 \mathrm{Ma}$ are common in VAL3 zircon ( $\sim 90 \%$ of the total number of grains), but are absent in samples VAL1, VAL2, and VAL4. We therefore suggest that the early formation of recrystallization rims played a major role in preserving zircon from the Alpine overprint. Recrystallized zircon is more resistant to metamictization (low $\mathrm{U}$ and $\mathrm{Th}$ ) and is structurally more stable (lower strain due to the low traceelement content), which makes it potentially less reactive. The preservation of abundant zircon rims with Cambrian ages and the absence of Alpine overgrowth indicate that significant dissolution, recrystallization or new formation of zircon did not occur. Therefore, the rock portion from which VAL3 was sampled did neither experience any significant fluid input nor partial melting during the Alpine metamorphism. In this environment, the U-Pb system of the recrystallized zircon rims was largely unaffected by the amphibolite-facies overprint. Any effect of an Alpine overprint was limited to those few rims that yield scattered ages 
younger than $450 \mathrm{Ma}$.

The same argument could also be valid to account for the preservation of VAL3 zircon during the Variscan metamorphism. Because little is known on the distribution and range of $P T$ conditions in the Valle d'Arbedo basement at that time (Gebauer 1993), any further interpretation on the reasons of zircon preservation during the Variscan metamorphism is conjectural.

\section{Zircon microstructure}

TEM imaging of the core of zircon VAL3-29 has revealed weak but pervasive lattice strain possibly due to radiation damage (metamictization). Structural defects such as microscale pores (not to be confused with the nanoscale pores of the rim) and dislocations have been observed in the core, but only at healed cracks (Fig. 5c), never in the crystal bulk. These defects are therefore considered uncharacteristic of primary zircon. In particular, the absence of dislocations in the bulk of the zircon core suggests that any lattice stress induced by the incorporation of different levels of trace elements in successive growth zones is easily accommodated by elastic distortion without the need for dislocations to nucleate.

The absence of submicrometer zoning from TEM images in the core of Valle d'Arbedo zircon is in contrast with the strong oscillatory zoning observed at a larger scale using CL. We suggest that, in the relatively small regions studied using TEM, the scale of growth banding is not amenable to imaging. Alternatively, submicrometer zoning could in fact be present at a suitable scale, but, because the chemical zoning obvious with CL corresponds to so small elastic strain (change in unit-cell dimensions), TEM images are apparently unperturbed. Research by Finch et al. (2001) supports the latter, as it shows that high-level substitution of elements into zircon result in unit-cell swelling of just $1 \%$.

Consequently, the core of VAL3-29 zircon is characterized by only weak internal strain (dappling attributed to radiation damage) and very few structural defects (no pores, no dislocations except at healed cracks, no submicrometer zoning). Nevertheless, it is obvious that this grain was able to recrystallize (i.e., the rim formed). This indicates that the occurrence of a large amount of structural defects is not a necessary condition for recrystallization to take place in zircon.

The rim of zircon VAL3-29 has a non-metamict microstructure but contains structural defects such as nanoscale pores and strain centers. The interpretation of pores is based upon an extensive literature dealing with TEM imaging in materials containing voids and bubbles (e.g., Ruedl et al. 1976). In brief, a characteristic fringe contrast (McLaren 1991, p. 167 and p. 309-310; Williams and Carter 1996, p. 451-452) can be imaged by TEM around any "hole" in an otherwise solid specimen. The exact nature of the fringes and their location relative to the edges of each hole is highly dependent on the imaging conditions, particularly image focus. At both of the defects marked NP in Figure 5d, a set of concentric circular fringes, alternately bright and dark, is clearly visible and is the type of evidence we used to infer the presence of nanopores. According to several authors (Putnis 2002; Geisler et al. 2007; Nasdala et al. 2009), the occurrence of pores in the rim is consistent with fluid-driven reactions, during which old zircon is replaced by new zircon.

The nature of the 5-30 nm strain centers (SC in Fig. 5d) cannot be established using TEM since they are totally imbedded in a foil, which is a few hundred nanometers thick. Consequently, reliable data on chemical signature and informative high-resolution TEM images cannot be collected. The strain centers differ from the nanoscale pores in that they show no fringing but appear as black spots in an otherwise bright and uniform matrix. Some previous studies on various materials have labeled this effect as "black spot contrast" (Schober and Balluffi 1969, in gold; Schober 1970, in silver; Bursill and McLaren 1966 and Chakoumakos et al. 1987, in zircon; Carter and Kohlstedt 1981, in quartz). In all these studies, and in Harlov et al. (2011, in monazite), the defects associated with such black spots are either known (in the quartz case, electron irradiation steadily produced new black spots) or interpreted to be due to radiation damage. Here we use instead the descriptive term "strain center" to identify a small defect (10-30 nm dark spot in BF TEM diffraction contrast image), which is still dense crystal but different to the surrounding matrix crystal (imaged uniformly bright). Such defects are characterized by a distortion or elasticstrain field (Bursill and McLaren 1966) that is highest at the center of the defect and falls away quickly with radius.

Even if their origin is speculative, the strain centers are obviously found exclusively in the trace-element-poor rim of the zircon crystal, suggesting that their formation is intimately related to recrystallization. Strain centers could be interpreted as chemical residues that locally stress and strain the crystal, which would make the features very obvious in TEM images. Formation of the rim could thus be viewed as a complex process, in which mass transport, trapping of chemical elements at strain centers and formation of a new crystal lattice can operate concomitantly when triggered by fluids (see also Hoskin and Black 2000; Harlov et al. 2011).

\section{Formation of the recrystallization rims}

Geisler et al. (2007) proposed two models to account for the formation of recrystallization rims. In the "diffusion-reaction" model, hydrous species diffuse through zircon heavily damaged by radiation and catalyze structural recovery. Nanoscale pores develop, non-formula elements such as $\mathrm{Ca}, \mathrm{Al}$, and $\mathrm{Fe}$ are gained and REE are lost. In the second model, "interfacecoupled dissolution-reprecipitation," a complete renewal of the zircon microstructure operates concomitantly with significant loss of REE. Pores up to a micrometer in size may form and no gain in non-formula elements is observed. In this latter model, metamictization of the parent zircon does not necessarily have to be high (Pidgeon et al. 1998; Tomaschek et al. 2003; Rubatto et al. 2008). Since the recrystallization rim of the Valle d'Arbedo zircon is characterized by the occurrence of nanoscale pores and low concentrations of non-formula elements such as $\mathrm{Ca}$, unequivocal distinction between the two proposed mechanisms is difficult. Nevertheless, given that the primary core is only slightly metamict at present time, $\sim 520 \mathrm{Ma}$ after crystallization, it is thought that zircon was not metamict when the rims recrystallized, making the diffusion-reaction model unlikely. This is confirmed by the $\alpha$-decay doses (Holland and Gottfried 1955) calculated for the zircon core with the highest $U$ and Th content (VAL3-8.2, see Table 1), with values ranging between $\sim 2.32 \times 10^{14} \alpha$-decay events/mg (assuming a recrystallization age of $\sim 470 \mathrm{Ma}$ ), and $1.45 \times 10^{15} \alpha$-decay events/mg (assuming a recrystallization age of $\sim 200 \mathrm{Ma}$ ). Both values are below 
the first metamictization stage of $3 \times 10^{15} \alpha$-decay events $/ \mathrm{mg}$ (Murakami et al. 1991).

The nanoscale pores in the studied zircon rim are interpreted as remnants of transport channels resulting from interface-coupled dissolution-reprecipitation. As diffusion of trace elements in zircon is too slow (Cherniak et al. 1997) to produce any appreciable change in chemistry at the temperature of recrystallization $\left(550-650{ }^{\circ} \mathrm{C}\right)$, it is thought that larger porosity at the time of recrystallization served as an exit from the crystal for $90-95 \%$ of the trace elements that were initially present in the core and are now absent in the recrystallization rim. The amount of porosity is a direct function of the difference in solubility between the parent and product zircon in the interfacial fluid and the difference in their molar volumes (Tomaschek et al. 2003; Geisler et al. 2003), but it is well known that pores tend to shrink with time (Putnis et al. 2005). Hence, it can be concluded that the scattered nanoscale pores observed in the rim are remnants of transport channels present at the time of recrystallization. We suggest that annealing was responsible for the nearly complete reduction of porosity, consistent with conclusions reached by Harlov et al. (2011) about synthetic rim formation in monazite. Given the mostly Ordovician age of the recrystallization rims, it is likely that annealing occurred soon after recrystallization. If annealing occurred later in the rock evolution, then it did not affect significantly the U-Pb system.

It must be noted that the recrystallization process in Valle d'Arbedo zircon is different from those reported by some other recent studies proposing dissolution-reprecipitation as the main zircon recrystallizaton mechanism (e.g., Rubatto et al. 2008; Hay and Dempster 2009; Hay et al. 2010). The aggregates of zircon microcrystals from the Lanzo eclogite studied by Rubatto et al. (2008) are euhedral and disconnected, though only slightly, from the parent zircon grain. New results have shown that dynamic recrystallization involving brittle and possibly also crystal-plastic deformation of zircon played a major role at the onset of microcrystal aggregate formation (own unpublished work). The zircon outgrowths studied by Hay and Dempster (2009) and Hay et al. (2010) are hydrothermal rims resulting from low-grade dissolution and reprecipitation of zircon. They do not display the morphological features observed in the Valle d'Arbedo grains, such as the smoothly curved inward-penetrating embayments of the core-rim boundary. Unlike the Valle d'Arbedo rims, the outgrowths are enriched in non-formula elements and have been formed at the expense of highly porous zircon. Finally, in all the above studies, dissolution, and reprecipitation mechanisms are temporally and/or spatially disconnected, whereas it is thought that the rims of the Valle d'Arbedo zircon crystals result from an in situ and contemporaneous interface-coupled dissolutionreprecipitation mechanism triggered by fluids.

To summarize, the chemical, isotopic, and microstructural study of Valle d'Arbedo zircon cores and recrystallization rims reveals that natural non-metamict zircon with very few defects and moderate trace-element content can efficiently recrystallize at relatively low temperatures. The growth of rim at the expense of core was topotactic and occurred via a recrystallization front that migrated into a pre-existing grain. Recrystallization occurred at $T<650{ }^{\circ} \mathrm{C}$ and appears not to be related to the amphibolite to granulite-facies metamorphism that produced the main rock assemblage. Nanoscale pores testify to the likely presence of fluid during recrystallization. The process was chemically very efficient and eliminated $90-95 \%$ of the trace elements present in the original zircon. Recrystallization and loss of elements was associated with either low, nanoscale porosity or, more likely, large pores and transport channels that later annealed. The final result is a non-metamict zircon rim that is low in porosity and inclusions. Therefore, it is proposed that recrystallization and annealing actually contributed to the chemical, isotopic, and structural preservation of the Valle d'Arbedo zircon crystals, which survived the Variscan and Alpine overprint.

\section{ACKNOWLEDGMENTS}

The authors are very grateful to Harri Kokkonen for his skillful sample preparation, to Frank Brink for his assistance during SEM work, and to Charlotte Allen for her technical support in the LA-ICP-MS lab at RSES, ANU. Alfons Berger is thanked for guiding an excursion in Valle d'Arbedo and discussion on the geology of the area. We also thank Thorsten Geisler and Lutz Nasdala for their constructive comments on a previous version and Jeff Nottage for improving the English language. Reviews by Fernando Corfu and Steven Reddy helped to improve the content and clarity of the paper. This work was supported by the Swiss National Science Foundation under research grant PBFR2-116949 and the Australian Research Council.

\section{REFERENCES CITED}

Belousova, E.A., Griffin, W.L., O’Reilly, S.Y., and Fischer, N.I. (2002) Igneous zircon: trace element composition as an indicator of source rock type. Contributions to Mineralogy and Petrology, 143, 602-622.

Berger, A., Mercolli, I., and Engi, M. (2005) The Lepontine Alps: notes accompanying the tectonic and petrographic map sheet Sopra Ceneri $(1: 100000)$. Schweizerische Mineralogische und Petrographische Mitteilungen, 85, 109-146.

Berger, A., Burri, T., Alt-Epping, P., and Engi, M. (2008) Tectonically controlled fluid flow and water-assisted melting in the middle crust: an example from the Central Alps. Lithos, 102, 598-615.

Black, L.P., Williams, I.S., and Compston, W. (1986) Four zircon ages from one rock: the history of a 3930 Ma-old granulite from Mount Sones, Enderby Land, Antarctica. Contributions to Mineralogy and Petrology, 94, 427-437.

Black, L.P., Kamo, S.L., Allen, C.M., Aleinikoff, J.M., Davis, D.W., Korsch, R.J., and Foudoulis, C. (2003) TEMORA 1: a new zircon standard for Phanerozoic $\mathrm{Pb}$ geochronology. Chemical Geology, 200, 155-170.

Burri, T., Berger, A., and Engi, M. (2005) Tertiary migmatites in the Central Alps: regional distribution, field relations, conditions of formation, and tectonic implications. Schweizerische Mineralogische und Petrographische Mitteilungen, 85, 215-232.

Bursill, L.A. and McLaren, A.C. (1966) Transmission electron microscope study of natural radiation damage in zircon $\left(\mathrm{ZrSiO}_{4}\right)$. Physica status solidi (b), 13, 331-343.

Capitani, G.C., Leroux, H., Doukhan, J.C., Ríos, S., Zhang, M., and Salje, E.K.H. (2000) A TEM investigation of natural metamict zircons: structure and recovery of amorphous domains. Physics and Chemistry of Minerals, 27, 545-556.

Carter, C.B. and Kohlstedt, D.L. (1981) Electron irradiation damage in natural quartz grains. Physics and Chemistry of Minerals, 7, 110-116.

Chakoumakos, B.C., Murakami, T., Lumpkin, G.R., and Ewing, R.C. (1987) Alpha-decay-induced fracturing in zircon: the transition from the crystalline to the metamict state. Science, 236, 1556-1559.

Cherniak, D.J., Hanchar, JM., and Watson, E.B. (1997) Diffusion of tetravalent cations in zircon. Contributions to Mineralogy and Petrology, 127, 383-390.

Claoué-Long, J.C., Compston, W., and Cowden, A. (1988) The age of the Kambalda greenstones resolved by ion-microprobe: implications for Archean dating methods. Earth and Planetary Science Letters, 89, 239-259.

Corfu, F., Hanchar, J.M., Hoskin, P.W.O., and Kinny, P.D. (2003) Atlas of zircon textures. In J.M. Hanchar and P.W.O. Hoskin, Eds., Zircon, 53, p. 469-500. Reviews in Mineralogy and Geochemistry, Mineralogical Society of America, Chantilly, Virginia.

Degeling, H., Eggins, S.M., and Ellis, D.J. (2001) Zr budgets for metamorphic reactions, and the formation of zircon from garnet breakdown. Mineralogical Magazine, 65, 749-758

Eggins, S.M., Kinsley, L.P.J., and Shelley, J.M.G. (1998) Deposition and element fractionation processes during atmospheric pressure laser sampling for analysis by ICP-MS. Applied Surface Science, 127, 278-286.

Finch, R.J., Hanchar, J.M., Hoskin, P.W.O., and Burns, P.C. (2001) Rare earth elements in synthetic zircon: Part 2. A single crystal X-ray study of xenotime substitution. American Mineralogist, 86, 681-689. 
Fraser, G., Ellis, D.J., and Eggins, S.M. (1997) Zirconium abundance in granulitefacies minerals, with implications for zircon geochronology in high-grade rocks. Geology, 25, 607-610.

Gebauer, D. (1993) The pre-Alpine evolution of the continental crust in the Central Alps-An overview. In J.F. Von Raumer and F. Neubauer, Eds., Pre-Mesozoic Geology in the Alps, p. 93-117. Springer Verlag, Berlin.

Geisler, T., Trachenko, K., Ríos, S., Dove, M.T., and Salje, E.K.H. (2003) Impact of self-irradiation damage on the aqueous durability of zircon $\left(\mathrm{ZrSiO}_{4}\right)$ : implications for its suitability as a nuclear waste form. Journal of Physics, Condensed Matter, 15, L597-L605.

Geisler, T., Schaltegger, U., and Tomaschek, F. (2007) Re-equilibration of zircon in aqueous fluids and melts. Elements, 3, 43-50.

Harlov, D.E., Wirth, R., and Hetherington, C.J. (2011) Fluid-mediated partial alteration in monazite: the role of coupled dissolution-reprecipitation in element redistribution and mass transfer. Contributions to Mineralogy and Petrology, 162, 329-348.

Hay, D.C. and Dempster, T.J. (2009) Zircon behaviour during low-temperature metamorphism. Journal of Petrology, 50, 571-589.

Hay, D.C., Dempster, T.J., Lee, M.R., and Brown, D.J. (2010) Anatomy of a low temperature zircon outgrowth. Contributions to Mineralogy and Petrology, $159,81-92$.

Headley, T.J., Ewing, R.C., and Haaker, R.F. (1981) Amorphous structure of metamict minerals observed by TEM. Nature, 293, 449-450.

Holland, H.D. and Gottfried, D. (1955) The effect of nuclear radiation on the structure of zircon. Acta Crystallographica, 8, 291-300.

Hoskin, P.W.O. and Black, L.P. (2000) Metamorphic zircon formation by solidstate recrystallization of protolith igneous zircon. Journal of Metamorphic Geology, 18, 423-439.

Hoskin, P.W.O. and Schaltegger, U. (2003) The composition of zircon in igneous and metamorphic petrogenesis. In J.M. Hanchar, and P.W.O. Hoskin, Eds., Zircon, 53, p. 27-62. Reviews in Mineralogy and Geochemistry, Mineralogical Society of America, Chantilly, Virginia.

Leroux, H., Reimold, W.U., Koeberl, C., Hornemann, U., and Doukhan, J.C. (1999) Experimental shock deformation in zircon: a transmission electron microscopic study. Earth and Planetary Science Letters, 169, 291-301.

Ludwig, K.R. (2003) Isoplot/Ex version 3.0. A geochronological toolkit for Microsoft Excel, p. 70. Berkeley Geochronological Center Special Publication, Berkeley.

McLaren, A.C. (1991) Transmission Electron Microscopy of Minerals and Rocks, 387 p. Cambridge University Press, U.K.

McLaren, A.C., Fitz Gerald, J.D., and Williams, I.S. (1994) The microstructure of zircon and its influence on the age determination from $\mathrm{Pb} / \mathrm{U}$ isotopic ratios measured by ion microprobe. Geochimica et Cosmochimica Acta, 58, 993-1005.

Murakami, T., Chakoumakos, B.C., Ewing, R.C., Lumpkin, G.R., and Weber, W.J. (1991) Alpha-decay event damage in zircon. American Mineralogist, $76,1510-1532$.

Nasdala, L., Kronz, A., Wirth, R., Váczi, T., Pérez-Soba, C., Willner, A., and Kennedy, A.K. (2009) The phenomenon of deficient electron microprobe totals in radiation-damaged and altered zircon. Geochimica et Cosmochimica Acta, $73,1637-1650$

Nemchin, A.A. and Pidgeon, R.T. (1997) Evolution of the Darling Range Batholith, Yilgarn Craton, Western Australia: a SHRIMP zircon study. Journal of Petrology, 38, 625-649.

Palenik, C.S., Nasdala, L., and Ewing, R.C. (2003) Radiation damage in zircon. American Mineralogist, 88, 770-781.

Pan, Y. (1997) Zircon- and monazite-forming metamorphic reactions at Manitouwadge, Ontario. Canadian Mineralogist, 35, 105-118.

Pidgeon, R.T. (1992) Recrystallization of oscillatory-zoned zircon: some geochronological and petrological implications. Contributions to Mineralogy and Petrology, 110, 463-472.

Pidgeon, R.T., Nemchin, A.A., and Hitchen, G.J. (1998) Internal structures of zircons from Archaean granites from the Darling Range batholith: implications for zircon stability and the interpretataion of zircon U-Pb ages. Contributions to Mineralogy and Petrology, 132, 288-299.

Putnis, A. (2002) Mineral replacement reactions: from macroscopic observations to microscropic mechanisms. Mineralogical Magazine, 66, 689-708.

Putnis, C.V., Tsukamoto, K., and Nishimura, Y. (2005) Direct observations of pseudomophism: compositional and textural evolution at a fluid-solid interface. American Mineralogist, 90, 1909-1912.

Roberts, M.P. and Finger, F. (1997) Do U-Pb ages from granulites reflect peak metamorphic conditions? Geology, 25, 319-322.
Rubatto, D. (2002) Zircon trace element geochemistry: distribution coefficients and the link betwen U-Pb ages and metamorphism. Chemical Geology, 184, 123-138.

Rubatto, D. and Gebauer, D. (2000) Use of cathodoluminescence for U-Pb zircon dating by ion microprobe: some examples from the Western Alps. In M. Pagel, V. Barbin, P. Blanc, and D. Ohnenstetter, Eds., Cathodoluminescence in Geosciences, p. 373-400. Springer Verlag, Berlin.

Rubatto, D., Müntener, O., Barnhoorn, A., and Gregory, C. (2008) Dissolutionreprecipitation of zircon at low-temperature, high-pressure conditions (Lanzo Massif, Italy). American Mineralogist, 93, 1519-1529.

Rubatto, D., Hermann, J., Berger, A., and Engi, M. (2009) Protracted fluid-induced melting during Barrovian metamorphism in the Central Alps. Contributions to Mineralogy and Petrology, 158, 703-722.

Ruedl, E., Gautsch, O., and Starotse, E. (1976) Transmission electron microscopy of He-bubbles in aluminium. Journal of Nuclear Materials, 62, 63-72.

Schaltegger, U., Fanning, C.M., Günther, D., Maurin, J.C., Schulmann, K., and Gebauer, D. (1999) Growth, annealing and recrystallization of zircon and preservation of monazite in high-grade metamorphism: conventional and in-situ U-Pb isotope, cathodoluminescence and microchemical evidence. Contributions to Mineralogy and Petrology, 134, 186-201.

Schiotte, L., Compston, W., and Bridgwater, D. (1989) Ion probe U-Th-Pb dating of polymetamorphic orthogneisses from northern Labrador, Canada. Canadian Journal of Earth Sciences, 26, 1533-1556.

Schober, T. (1970) Defects produced in silver by keV silver ion bombardment. Physica status solidi (a), 1, 307-313.

Schober, T. and Balluffi, R.W. (1969) Formation of vacancy clusters by dechanneling of channeled keV gold ions in gold. Canadian Journal of Physics, 47, 1221-1229.

Stacey, J.S. and Kramers, J.D. (1975) Approximation of terrestrial lead evolution by a two-stage model. Earth and Planetary Science Letters, 26, 207-221.

Strecker, A., Mayer, J., Baretzky, B., Eigenthaler, W., Gemming, T., Schweinfest, R., and Rühle, M. (1999) Optimization of TEM specimen preparation by double-sided ion beam thinning under low angles. Journal of Electron Microscopy, 48, 235-244.

Tomaschek, F., Kennedy, A.K., Villa, I.M., Lagos, M., and Ballhaus, C. (2003) Zircons from Syros, Cyclades, Greece-Recrystallization and mobilization of zircon during high-pressure metamorphism. Journal of Petrology, 44, 1977-2002.

van Breemen, O., Henderson, J.B., Loveridge, W.D., and Thompson, P.H. (1987) $\mathrm{U}-\mathrm{Pb}$ zircon and monazite geochronology and zircon morphology of granulite from the Thelon Tectonic Zone, Healey Lake and Artillery Lake map areas, NWT. Geological Survey of Canada Papers, 87, 783-801.

Vavra, G., Gebauer, D., Schmid, R., and Compston, W. (1996) Multiple zircon growth and recrystallisation during polyphase Late Carboniferous to Triassic metamorphism in granulites of the Ivrea Zone (Southern Alps): an ion microprobe (SHRIMP) study. Contributions to Mineralogy and Petrology, 122, 337-358.

Vavra, G., Schmid, R., and Gebauer, D. (1999) Internal morphology, habit and $\mathrm{U}-\mathrm{Th}-\mathrm{Pb}$ microanalysis of amphibolite-to-granulite facies zircons: geochronology of the Ivrea Zone (Southern Alps). Contributions to Mineralogy and Petrology, 134, 380-404.

Watson, E.B. and Harrison, T.M. (2005) Zircon thermometer reveals minimum melting conditions on earliest Earth. Science, 308, 841-844.

Watson, E.B., Wark, D.A., and Thomas, L.E. (2006) Crystallization thermometers for zircon and rutile. Contributions to Mineralogy and Petrology, 151, 413-433.

Weber, W.J., Ewing, R.C., and Wang, L.M. (1994) The radiation-induced crystalline-to-amorphous transition in zircon. Journal of Materials Research, 9, 688-698.

Williams, D.B. and Carter, C.B. (1996) Transmission Electron Microscopy: a textbook for Materials Science. 729 p. Springer Verlag, New York.

Williams, I.S. (1998) U-Th-Pb geochronology by ion microprobe. Reviews in Economic Geology, 7, 1-35.

Yada, K., Tanji, T., and Sunagawa, I. (1987) Radiation-induced lattice defects in natural zircon $\left(\mathrm{ZrSiO}_{4}\right)$ observed at atomic resolution. Physics and Chemistry of Minerals, 14, 197-204.

MANUSCRIPT RECEIVED APRIL 5, 2011

MANUSCRIPT ACCEPTED OCTOBER 12, 2011

MANUSCRIPT HANDLED BY DANIEL HARLOV 